Beata Zarzycka*

Lublin

\title{
Psychologiczne koncepcje przebaczenia w relacjach międzyludzkich
}

Doznalibyśmy pociechy, gdybyśmy mogli zapomnieć o przeszłości, której nie możemy zmienić. Gdybyśmy potrafili zapomnieć o najbardziej okrutnych chwilach - w miarę upływu czasu uwolnilibyśmy się od bólu. Lecz to, co złe, jak chwast tkwi w naszej pamięci. Jedynym sposobem na usunięcie go jest zabieg chirurgiczny zwany przebaczeniem.

Smedes, The Art of Forgiving**

Przebaczenie ma długą historię rozważań na polu filozofii i teologii, zwłaszcza teologii chrześcijańskiej¹. W psychologii ważność pojęcia „,przebaczenie" w kulturze zachodniej dostrzegł Milton Rokeach². Włączył wartość instrumentalną ,przebaczający” (forgiving) do swoich badań nad prefe-

* S. dr Beata Zarzycka jest adiunktem w Katedrze Psychologii Społecznej i Psychologii Religii w Instytucie Psychologii Katolickiego Uniwersytetu Lubelskiego Jana Pawła II. Adres: Instytut Psychologii KUL, Aleje Racławickie 14, 20-950 Lublin; e-mail: zarzycka@ kul.lublin.pl.

** Michael E. McCullough, Charlotte van Oyen Witvliet, „The Psychology of Forgiveness", w: Handbook of positive psychology, red. Charles R. Snyder, Shane J. Lopez (New York, NY: Oxford University Press, 2002), 446.

${ }^{1}$ Michael E. McCullough, Everett L. Worthington, „Models of interpersonal forgiveness and their applications to counseling: Review and critique", Counseling and Values 39,1 (1994): 2-14.

${ }^{2}$ Milton Rokeach, The nature of human values (New York: Free Press, 1973). 
rencją wartości. Powszechniejsze jednak zainteresowanie tym zagadnieniem datuje się na koniec lat 80., a jego źródłem są doświadczenia psychologów praktyków. Dostrzegli oni możliwość zastosowania przebaczenia w terapii osób skrzywdzonych, zwłaszcza wśród kobiet - ofiar nadużyć seksualnych, kazirodztwa i przemocy domowej. Profesjonaliści, korzystając z tradycji religijnej, w tego rodzaju sytuacjach intuicyjnie proponowali przebaczenie jako rozwiązanie mogące pomóc $\mathrm{w}$ radzeniu sobie $\mathrm{z}$ doświadczeniem krzyw$\mathrm{dy}^{3}$. Badacze z zakresu psychologii poczynili z kolei postępy w definiowaniu i pomiarze przebaczenia, a także w eksploracji jego predyktorów i funkcji w obszarze dobrostanu i jakości życia ${ }^{4}$.

\section{Psychologiczne definicje przebaczenia}

Psychologiczne definicje przebaczenia różnią się w zależności od dziedziny psychologii, którą reprezentuje autor ${ }^{5}$. Bogatym źródłem definicji jest bez wątpienia obszar psychoterapii. Chociaż każda definicja zachowuje swą odrębność dzięki powiązaniu ze szkołą terapeutyczną autora i jego poglądem na znaczenie przebaczenia w terapii, to ich wspólną cechą jest akcentowanie procesualnych aspektów przebaczenia. Wiele definicji sformułowano w ramach psychologii akademickiej, zwłaszcza rozwojowej i społecznej. Ostatnim źródłem definicji jest obszar psychologii pastoralnej, uprawianej głównie w kontekście wiary chrześcijańskiej. Psychologowie pastoralni rozumieją przebaczenie jako proces psychologiczno-duchowy, w którym istotną rolę odgrywa więź człowieka z Bogiem 6 .

Procesualne definicje przebaczenia koncentrują się na opisie procesów, poprzez które przebaczenie się dokonuje. Na przykład Richard Fitzgibbons definiuje przebaczenie jako proces, w którym następuje ułaskawienie ko-

3 Rafał P. Bartczuk, „Postawa religijna a gotowość do przebaczenia. Badania empiryczne" (niepublikowana praca magisterska, Katolicki Uniwersytet Lubelski, 1999); Suzanne Freedman, Tiffany Zarifkar, „The Psychology of Interpersonal Forgiveness and Guidelines for Forgiveness Therapy: What Therapists Need to Know to Help Their Clients Forgive", Spirituality in Clinical Practice, http://dx.doi.org/10.1037/scp0000087: 3.

${ }^{4}$ McCullough, van Oyen Witvliet, ,The Psychology”, 446-458.

5 Debra Kaminer, Dan J. Stein, Irene Mbanga, Nompumelelo Zungu-Dirwayi, „Forgiveness: Toward an integration of theoretical models", Psychiatry 63,4 (2000): 344-357.

${ }^{6}$ Bartczuk, „Postawa”, 20; Wei Neng Lin, Robert D. Enright, John S. Klatt, „A forgiveness intervention for Taiwanese young adults with insecure attachment", Contemporary Family Therapy 35,1 (2013): 105-120. 
goś lub doprowadzenie do końca odczuwania urazy względem niego. Autor odróżnia przebaczenie intelektualne od emocjonalnego. Pierwsze polega na podjęciu decyzji o przebaczeniu. Drugie jest emocjonalnym odczuciem, że dokonał się akt przebaczenia ${ }^{7}$. Innym przykładem jest definicja Davida Augsburgera odnosząca się do przebaczenia w bliskich relacjach interpersonalnych, takich jak przyjaźń lub małżeństwo. Przebaczenie polega tutaj na odnowieniu miłości i jest oparte na rozróżnieniu między osobą a czynem, którego ta osoba jest sprawcą ${ }^{8}$. Przykładem procesualnego ujęcia przebaczenia na gruncie polskim jest definicja Jerzego Mellibrudy, zgodnie z którą centralne dla przebaczenia jest wyzwalanie się spod destrukcyjnego wpływu

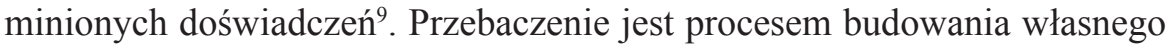
ładu wewnętrznego, konstruktywnym porządkowaniem tych uczuć, wyobrażeń i sposobów reagowania, które zostały zaburzone przez doświadczenie krzywdy. Z uwagi na procesualny charakter definicje te służą celom psychoterapii: ułatwiają zrozumienie własnych przeżyć i podjęcie zadań prowadzących do przepracowania krzywdy. Wciąż wzrasta liczba danych empirycznych potwierdzających pozytywną rolę przebaczenia jako narzędzia terapeutycznego dla tych, którzy doznali głębokich krzywd ${ }^{10}$.

Za przykład definicji wypracowanej w uznanych ramach metodologicznych psychologii może posłużyć propozycja Roberta Enrighta i jego współpracowników (The Human Development Study Group - HDSG) oraz definicja Michaela McCullougha ${ }^{11}$. Pierwsza nawiązuje do koncepcji rozwoju człowieka, druga wyrosła wokół wypracowanego na obszarze psychologii społecznej pojęcia postawy. Enright określił przebaczenie jako „akt osoby niesprawiedliwie skrzywdzonej polegający na dokonanym $\mathrm{z}$ rozmysłem

7 Richard P. Fitzgibbons, „The cognitive and emotive uses of forgiveness in the treatment of anger", Psychotherapy: Theory, Research, Practice, Training 23,4 (1986): 629-633.

${ }^{8}$ David W. Augsburger, Sztuka przebaczania (Warszawa: Vocatio, 1995), 38.

9 Jerzy Mellibruda, Pułapka niewybaczonej krzywdy (Instytut Psychologii Zdrowia i Trzeźwości. Polskie Towarzystwo Psychologiczne, 1995).

${ }^{10}$ Michael E. McCullough, William T. Hoyt, Chris Rachal, „What we know (and need to know) about assessing forgiveness constructs", w: Forgiveness: Theory, research, and practice, red. Michael E. McCullough, Kenneth I. Pargament, Carl E. Thoresen (New York-London: The Guilford Press, 2000), 65-88.

${ }^{11}$ Robert D. Enright, The Human Development Study Group, „Counseling with the forgiveness triad: On forgiving, receiving forgiveness, and self-forgiveness”, Counseling \& Values 40 (1996): 107-126; Michael E. McCullough, „Forgiveness as human strength: Theory, measurement, and links to well-being”, Journal of Social and Clinical Psychology 19,1 (2000): 43-55. 
porzuceniu urazy względem krzywdziciela oraz na pielęgnowaniu w sobie niezasłużonych jakości: wielkoduszności i współczucia względem krzywdziciela"12. Przebaczenie dokonuje się dzięki odróżnieniu czynu krzywdziciela od niego samego jako osoby ludzkiej. McCullough w swojej definicji wyakcentował strukturalne aspekty postawy. Przebaczenie jest strategia rozwiązywania problemów, kompleksem zjawisk emocjonalnych, poznawczych i behawioralnych, w których negatywny afekt i osąd krzywdziciela jest zmniejszany, nie przez zaprzeczanie własnego prawa do takiego afektu, ale przez spojrzenie na krzywdziciela ze współczuciem i życzliwością przy świadomości, że krzywdziciel nie ma do tego prawa. Wśród polskich psychologów akademickich Eufrozyna Gruszecka zdefiniowała przebaczenie jako akt darowania winy oznaczający nie tylko ułaskawienie winowajcy i rezygnację z roszczeń w stosunku do niego, ale również uwolnienie winnego i siebie samego z potrzasku oraz zerwanie relacji o charakterze ,skrzywdzony-krzywdziciel"13.

Dla podejścia pastoralnego charakterystyczna jest integracja elementów teologicznych i psychologicznych. Od strony teorii psychologicznych dominuje tutaj podejście poznawcze, w którym akcentowana jest wolność człowieka w podejmowaniu decyzji i odpowiedzialność za ich konsekwencje. Od strony teologicznej pierwotne wobec przebaczenia krzywdzicielowi jest przyjęcie przebaczenia od Boga ${ }^{14}$. Przykładem pastoralnego ujęcia przebaczenia jest propozycja Dennisa i Matthew Linnów, którzy zdefiniowali przebaczenie jako uzdrawianie bolesnych wspomnień zachodzące wówczas, gdy bolesne momenty w życiu zostają uznane za błogosławieństwo zamiast za czynnik okaleczający. Przebaczenie jest duchowym i psychologicznym procesem wiodącym do akceptacji bolesnego zdarzenia z przeszłości, analogicznym do procesu akceptacji faktu własnej śmierci ${ }^{15}$. Spośród rodzimych autorów na obecność elementów psychologicznych i teologicznych w procesie przebaczenia zwracała uwagę Zenomena Płużek. Podkreślała złożoność procesu przebaczenia, rozróżniając w nim aspekty intelektualno-wolitywne,

${ }^{12}$ Suzanne R. Freedman, Robert D. Enright, „Forgiveness as an intervention goal with incest survivors", Journal of Consulting and Clinical Psychology 64, 5 (1996): 983.

${ }^{13}$ Eufrozyna Gruszecka, „Trudności w wybaczaniu krzywd osobistych”, Nowiny Psychologiczne 1 (1996): 41-55.

${ }_{14}$ Bartczuk, „Postawa”, 40.

15 Dennis Linn, Matthew Linn, Uzdrawianie ludzkich zranień poprzez pięć etapów przebaczenia (Kraków: Wydawnictwo M, 1993). 
emocjonalne i zmianę postawy. Intelekt umożliwia zrozumienie krzywdy. Procesy emocjonalne zachodzą dzięki umiejętności kierowania emocjami i doprowadzenia ich do dojrzałości. Zmiany w postawach dotyczą zarówno ustosunkowań wobec krzywdziciela, jak też doznanej krzywdy ${ }^{16}$.

Przedstawione psychologiczne definicje przebaczenia, choć wypracowane przez reprezentantów różnych dziedzin psychologii, zawierają cztery elementy wspólne. Po pierwsze, akcentują fakt, że osoba doznała krzywdy (fizycznej, emocjonalnej lub interpersonalnej), której charakter był głęboki, a konsekwencje - długofalowe. Po drugie, sprawcą krzywdy, niezależnie od intencji, jest inna osoba lub osoby. Po trzecie, osoba skrzywdzona dobrowolnie decyduje się na zmianę negatywnej postawy wobec sprawcy krzywdy - na zmniejszenie urazy i negatywnego afektu oraz rezygnację z pragnienia zemsty. Wreszcie, decyzja o przebaczeniu nie zależy od tego, czy sprawca wyrazi skruchę lub zadośćuczyni za krzywdę (choć fakt uzyskania przeproszenia ułatwia przebaczenie). Przebaczenie ma miejsce wówczas, gdy przebaczający zmniejsza negatywne myśli, uczucia i zachowania wobec sprawcy krzywdy i zaczyna akceptować jego wartość jako osoby. Dyskusyjna pozostaje nadal kwestia, czy przebaczenie wiąże się z równoczesnym wzrostem pozytywnych myśli i uczuć wobec sprawcy krzywdy ${ }^{17}$.

\section{Psychologiczne modele przebaczenia}

Michael McCullough i Everett Worthington zaproponowali, by opisane przez psychologów modele przebaczenia uporządkować w cztery kategorie. Do pierwszej należą modele oparte na klasycznych teoriach psychologicznych. Kategorię drugą tworzą modele procesualne, opisujące sekwencje zadań związanych z procesem przebaczenia. Trzecia kategoria zawiera modele oparte na koncepcji rozwoju moralnego, a czwarta - „typologie” przebaczenia $^{18}$. 2006).

${ }^{16}$ Aleksander Jacyniak, Zenomena Płużek, Świat ludzkich kryzysów (Kraków: WAM,

17 Freedman, Zarifkar, ,The Psychology”, 3.

${ }^{18}$ McCullough, Worthington, „Models”, 2. 


\section{Modele oparte na teoriach psychologicznych}

Psychologiczne modele przebaczenia powstały na gruncie teorii psychodynamicznej ${ }^{19}$, relacji z obiektem ${ }^{20}$, konstruktów osobistych ${ }^{21}$ i teorii poznawczych $^{22}$. Model psychodynamiczny wyjaśnia trudności w procesie przebaczenia jako rezultat naruszenia intrapsychicznych umów, ukształtowanych we wczesnym okresie dzieciństwa. Człowiek kształtuje zinternalizowane zasady w oparciu o dziecięca percepcję norm rodzicielskich dotyczących dobra i zła oraz towarzyszących im nagród i kar. Te dziecięce „kontrakty” są sztywne, legalistyczne i postrzegane jako uniwersalne. Zmieniają się one w procesie poznawczego rozwoju dziecka. Jednakże niektóre z tych zasad nie zmieniają się, ale wyznaczają standardy definiowania dobra i zła także w dorosłości. Kiedy inni nie respektują tych zasad, jednostka doświadcza gniewu, rozżalenia, zaciętych myśli, uczuć i ujawnia nieustępliwe zachowania. Przebaczenie w interpretacji psychodynamicznej obejmowałoby dwa etapy. Pierwszy polega na eliminacji tych sztywnych „kontraktów” definiujących dobro i zło nabytych w dzieciństwie. Drugi ma charakter intrapsychiczny i jest analogiczny do przebaczenia interpersonalnego. Po zweryfikowaniu dziecięcych przekonań jednostka odczuwa wstyd i poczucie winy, ponieważ te konstrukty determinowały jej zachowania wobec siebie i innych. Dojrzałe „ja” musi zatem najpierw wybaczyć dziecięcemu ,ja”, że dążyło do realizacji tych zasad. Dopiero wówczas jest zdolne do budowania dojrzałych relacji $\mathrm{z}$ innymi. Uzasadnione urazy mogą być podjęte $\mathrm{z}$ miłością, a nie $\mathrm{w}$ gniewie i zgorzknieniu ${ }^{23}$.

Innym przykładem jest model przebaczenia zaproponowany przez Michaela Smitha, nawiązujący do koncepcji konstruktów osobistych George'a Kelly'ego. W tej koncepcji jednostka aktywnie interpretuje swoje doświadczenia zgodnie z posiadanym systemem konstruktów. Zmiany psychologiczne są związane ze zmianami w systemie konstruktów osobistych umożliwia on, by doświadczenia były postrzegane w nowy sposób, lub apli-

19 Jared P. Pingleton, „The role and function of forgiveness in the psychotherapeutic process", Journal of Psychology and Theology 17 (1989): 27-35.

20 John Gartner, „The capacity to forgive: An object relations perspective”, Journal of Religion and Health 27, 4 (1988): 313-320.

${ }^{21}$ Michael Smith, „The psychology of forgiveness”, The Month 14 (1981): 301-307.

${ }^{22}$ David M. Droll, „Forgiveness, Theory and research” (niepublikowana rozprawa doktorska, Uniwersytet Nevady, 1984).

${ }^{23}$ Tamże, 2-14; James N. Lapsley, „Reconciliation, forgiveness, lost contracts”, Theology Today 23, 1 (1966): 44-59. 
kuje nowe konstrukty do ich interpretowania. W sytuacji idealnej, gdy do interpretacji doświadczeń osobistych aplikowane są nowe konstrukty, zmienia się również zachowanie jednostki ${ }^{24}$. Zaproponowany przez Smitha poznawczy model przebaczenia zakłada zastosowanie nowych systemów konstruktów do interpretacji raniących doświadczeń z przeszłości w taki sposób, by zyskały one nowe znaczenie. Na przykład opisy raniących interakcji z rodzicami mogą ewoluować od takich konstruktów jak , dobry-zły” do „zraniony-zdrowy” albo „doskonały-niedoskonały”. Dzięki zastosowaniu nowego konstruktu zraniona osoba odnosi się do rodziców raczej ze współczuciem i życzliwością niż mściwie i karząco ${ }^{25}$.

Modele przebaczenia oparte na klasycznych teoriach psychologicznych mają tę zaletę, że są wewnętrznie spójne. Każdy jest częścią większej teorii psychologicznej i może być użyteczny w obszarze praktycznym dla reprezentantów danej opcji teoretycznej. Niewiele jest badań empirycznych na gruncie tych modeli, ale wykazują one dużą użyteczność dla integracji danych empirycznych ${ }^{26}$.

\section{Procesualne modele przebaczenia}

Procesualne modele przebaczenia koncentrują się na sekwencjach zjawisk psychologicznych (intrapersonalnych) lub interpersonalnych zachodzących w przebaczeniu. Chociaż między poszczególnymi modelami występują różnice w liczbie, kolejności i treści tych sekwencji, podstawowe zadania opisywane w modelach procesualnych obejmują: przypominanie sobie krzywdy, podejmowanie decyzji o przebaczeniu, aktywność poznawczą i emocjonalną oraz zmianę zachowania.

W modelach interpersonalnego przebaczenia opisywana jest zarówno aktywność krzywdziciela, jak również aktywność osoby skrzywdzonej. Na przykład Augsburger opisał proces przebaczenia za pomocą pięciu etapów: (1) uświadomienie sobie popełnionego zła; (2) ponowne utwierdzenie miłości; (3) uwolnienie od przeszłości; (4) wspólne wyrażenie skruchy i (5) ponowne odkrycie wspólnoty ${ }^{27}$. Arthur Martin zaproponował model, w którym przebaczenie dokonuje się również w pięciu etapach: (1) rezygnacja

\footnotetext{
${ }^{24}$ George A. Kelly, The psychology of personal constructs (New York: Norton, 1955).

${ }^{25}$ Smith, „The psychology”, 301-307; McCullough, Worthington, „Models”, 2-14.

${ }_{26}$ McCullough, Worthington, „Models”, 2-14.

27 Augsburger, Sztuka.
} 
z poszukiwania zemsty lub akceptacja relacji jako całkowicie zerwanej; (2) wybaczenie lub pragnienie naprawienia relacji; (3) wyrażenie zarzutów lub wyjaśnień wobec sprawcy krzywdy; (4) wyrażenie skruchy przez krzywdziciela i (5) odnowienie wzajemnego zaufania w oparciu o wiarę ${ }^{28}$.

Modele intrapersonalne opisuja proces przebaczenia jako sekwencję kroków poznawczych, emocjonalnych i behawioralnych, które musi podjąć przebaczający, niezależnie od zachowania sprawcy po dokonaniu krzywdy. Przykładem takiego ujęcia jest model Enrighta, w którym przebaczenie jest sekwencją czterech faz. W pierwszej, tak zwanej fazie odkrywania, osoba uświadamia sobie ból emocjonalny, skutkujący poczuciem krzywdy. Do charakterystycznych doznań tej fazy należą: gniew, wstyd i poznawcze próby ataku w formie ciaggłego powracania w wyobraźni do raniącego wydarzenia. Faza druga (decyzja) polega na przemianie serca lub uzyskaniu nowego wglądu połączonego z uznaniem dotychczasowych strategii rozwiązania problemu za nieskuteczne. Osoba otwiera się na poszukiwanie przebaczenia jako możliwości wyjścia z sytuacji i wyraża zgodę na przebaczenie krzywdzicielowi. Kolejna, tak zwana faza pracy, obejmuje proces poznawczego przeformułowania, czyli zmian w postrzeganiu działań sprawcy krzywdy. Osoba dostrzega szerszy kontekst zdarzenia, naciski, którym podlegał sprawca, oraz historię jego osobistego rozwoju warunkującą jego działania. Poszerzanie horyzontu widzenia krzywdy i działania sprawcy nie ma na celu usprawiedliwiania sprawcy, ale ułatwia jego zrozumienie. Emocjonalnym odpowiednikiem poznawczego przeformułowania jest empatia. W czwartej, ostatniej fazie (wychodzenia) pojawia się przebaczenie, odczuwane jako poczucie zmniejszania się negatywnych i być może zwiększania się pozytywnych uczuć względem krzywdziciela, prowadzące do poczucia wewnętrznego, emocjonalnego uwolnienia ${ }^{29}$.

Guy Pettitt zaproponował model, w którym przebaczenie dokonuje się w pięciu etapach: (1) zobowiązanie się do przebaczenia jako sposobu poradzenia sobie z krzywdą; (2) przyjęcie pięciu nowych perspektyw (rozpoznanie niezaspokojonych potrzeb, które skłoniły sprawcę do wyrządzenia

${ }^{28}$ Arthur J. Martin, „A realistic theory of forgiveness”, w: The return to reason, red. John Wild (Chicago: Henry Regnery, 1953), 313-332; McCullough, Worthington, „Models", 2-14.

${ }^{29}$ Robert D. Enright, Catherine T. Coyle, „Researching the process model of forgiveness within psychological interventions", w: Dimensions of forgiveness: Psychological research and theological perspectives, red. Everett L. Worthington, Jr. (Philadelphia-London: Templeton Foundation Press, 1998), 139-161. 
krzywdy; uspokojenie się; otwarcie się na własną rolę w doświadczeniu krzywdy; pragnienie sprawiedliwych działań; dążenie do znalezienia dobra w innych); (3) zmiana dotychczasowego postrzegania krzywdy; (4) akceptacja krzywdy i anulowanie własnych wysokich oczekiwań; (5) przywracanie przepływu witalności i miłości ${ }^{30}$. Z perspektywy wiary chrześcijańskiej Colleen Benson zidentyfikował cztery kroki w procesie przebaczenia: (1) uświadomienie sobie dyskomfortu i gniewu związanego z doświadczeniem krzywdy; (2) identyfikacja z grzesznością krzywdziciela w celu wzbudzenia współczucia; (3) akceptacja przebaczenia, jakie Jezus darował tym, przez których został skrzywdzony; (4) przyjęcie gotowości do poniesienia grzechu sprawcy i wzbudzenie altruistycznych zachowań wobec niego ${ }^{31}$.

W literaturze polskiej procesualne ujęcie intrapersonalnego przebaczenia zaproponowali Jerzy Mellibruda i Ewa Woydyłło. Melibruda opisał przebaczenie jako sekwencję spotkań z wewnętrznymi doznaniami: bólem, lękiem, gniewem, smutkiem, bezsilnością, które prowadzą do budowania nowego porządku, poszukiwania lepszego miejsca w świecie i uporządkowania wartości ${ }^{32}$. Zdaniem Woydyłło proces przebaczenia rozpoczyna się od zrozumienia doznanej krzywdy i powolnego dochodzenia do świadomej decyzji o przebaczeniu, której skutkiem jest wyłonienie się nowego ,ja”. Proces ten zawiera następujące etapy: nazwanie krzywdy; rozpoznanie zmian spowodowanych przez krzywdę; określenie stopnia zniszczeń w osobowości; rozmowę o krzywdzie z krzywdzicielem lub kimś obiektywnym; uznanie krzywdy za własną; uznanie odpowiedzialności sprawcy; wyrównanie rachunków (np. uznanie sprawy za zamkniętą lub ukaranie krzywdziciela); odzyskanie poczucia wolności i mocy ${ }^{33}$.

Modele procesualne pozwalają widzieć zjawisko przebaczenia nie tyle jako pojedyncze zdarzenie, ale jako sekwencję doznań, myśli, uczuć i zachowań doświadczanych przez osobę skrzywdzoną, ułatwiając tym samym identyfikację, na którym etapie tej drogi znajduje się skrzywdzona osoba.

${ }^{30}$ McCullough, Worthington, „Models”, 2-14; Guy A. Pettitt, „Forgiveness: A teachable skill for creating and maintaining mental health", New Zealand Medical Journal 100 (1987): 180-182.

${ }^{31}$ McCullough, Worthington, „Models”, 2-14; Colleen K. Benson, „Forgiveness and the psychotherapeutic process", Journal of Psychology and Christianity 11 (1992): 76-81.

32 Mellibruda, Pułapka.

33 Ewa Woydyłło, Aby wybaczyć (Warszawa: Akuracik, 1998). 


\section{Modele rozwoju rozumienia pojęcia przebaczenia oparte na teorii rozwoju moralnego Kohlberga}

Enright i jego współpracownicy zastosowali opracowaną przez Lawrence'a Kohlberga teorię rozwoju moralnego człowieka do opisu kształtowania się rozumienia pojęcia przebaczenia ${ }^{34}$. Model Enrighta opiera się na założeniu, że jednostka, zwiększając zdolności poznawcze, staje się bardziej zdolna do przyjmowania perspektywy innych osób, wczuwania się w ich trudną sytuację i słabości oraz do akceptowania innych pomimo krzywd doświadczonych w przeszłości. Rozwój rozumienia pojęcia przebaczenia dokonuje się w sześciu etapach. Dwa najwcześniejsze etapy zachodzą wówczas, gdy w myśleniu dominuje egocentryzm, koncentracja na unikaniu bólu i poszukiwanie przyjemności. Przebaczenie jest tutaj postrzegane jako gest służący własnemu interesowi, np. potrzebie rewanżu lub uzyskania zadośćuczynienia. Na pierwszym etapie motywem przebaczenia jest pragnienie zemsty (,Mogę przebaczyć komuś, kto postapił źle przeciwko mnie, jeśli tylko będę mógł ukarać go w podobnym stopniu, w jakim ja sam doświadczyłem bólu"). Na etapie drugim przebaczenie jest motywowane potrzebą uzyskania wynagrodzenia lub zadośćuczynienia za doświadczone krzywdy (,Jeśli dostanę na powrót to, co zostało mi zabrane - mogę przebaczyć"). Etapy te korespondują z orientacją posłuszeństwa i kary oraz relatywizmu moralnego w koncepcji Kohlberga. Na środkowych etapach przebaczenie pojawia się w kontekście obowiązujących norm, oczekiwań społecznych oraz jako warunek harmonii społecznej ${ }^{35}$. Na etapie trzecim przebaczenie jest wynikiem presji społecznej („Przebaczam ponieważ inni oczekują tego ode mnie”). $\mathrm{Na}$ czwartym etapie - jest rezultatem oczekiwań instytucji, np. religijnych lub moralnych (,Przebaczam ponieważ moja religia lub podobna instytucja

${ }^{34}$ Robert D. Enright, The Human Development Study Group, „The moral development of forgiveness", w: Handbook of moral behaviour and development, red. William M. Kurtines, Jacob Gewirtz (Hillsdale, NJ: Erlbaum, 1991), 123-152; Robert D. Enright, „Piaget on the moral development of forgiveness: Identity or reciprocity?", Human Development 37, 2 (1994): 63-80; Robert D. Enright, Elizabeth A. Gassin, Ching-Ru Wu. „Forgiveness: A developmental view", Journal of Moral Education 21 (1992): 99-114; Robert D. Enright, „Counseling within the forgiveness triad: On forgiving, receiving forgiveness, and self-forgiveness”, Counseling and Values 40, 2 (1996): 107-126; Lawrence Kohlberg, „Moral stage and moralization: The cognitive-developmental approach to socialization”, w: Moral development and behavior: Theory, research, and social issues, red. Thomas Lickona (New York: Holt, Rinehart and Winston, 1976), 31-53.

${ }^{35}$ Robert D. Enright, Maria JD Santos, Radhi Al-Mabuk. „The adolescent as forgiver”, Journal of adolescence 12, 1 (1989): 95-110. 
domaga się tego"). Na piątym etapie przebaczenie jest warunkiem utrzymania harmonii społecznej („Przebaczam, ponieważ to wprowadza na nowo harmonię lub dobre relacje w społeczeństwie”). W koncepcji rozwoju moralnego Kohlberga rozumienie pojęcia przebaczenia właściwe dla środkowych etapów koresponduje z orientacją dobrego chłopca/dziewczyny, prawa i porządku oraz umowy społecznej i legalizmu ${ }^{36}$. Ostatni, szósty etap pojmowania przebaczenia cechuje się autentycznym zainteresowaniem dobrem innych osób oraz promowaniem harmonii interpersonalnej („Przebaczam ponieważ muszę naprawdę troszczyć się o każdą osobę. Jej raniący czyn nie zmienia tego znaczenia miłości”). Enright i jego współpracownicy określali ten etap ,przebaczenie jako miłość”. Taki sposób myślenia pociąga za sobą przebaczenie bezwarunkowe, oparte na zasadzie miłości, zamykające drzwi przed zemstą i otwarte na pojednanie ${ }^{37}$. Etap ten koresponduje $\mathrm{z}$ orientacją uniwersalnych zasad sumienia w koncepcji Kohlberga ${ }^{38}$.

\section{Typologie przebaczenia}

Trzej badacze (Michele Nelson, Mary Trainer i Glenn Veenstra) podjęli próby opracowania typologii przebaczenia na podstawie cech, które je różnicują ${ }^{39}$. Trainer wyróżniła trzy typy przebaczenia: (1) przebaczenie bez zrozumienia - jest to jawna manifestacja przebaczenia, któremu towarzyszy lęk, niepokój i resentyment; (2) przebaczenie instrumentalne - będące doraźnym środkiem uzyskania innego celu poprzez protekcjonalność i wrogość; (3) przebaczenie wewnętrzne, które charakteryzuje się zmianą w postawach i uczuciach wobec sprawcy krzywdy oraz behawioralnymi przejawami przebaczenia i dobrej woli. $Z$ kolei Nelson, na podstawie behawioralnych i emocjonalnych zmian w ustosunkowaniach wobec krzywdziciela, rozróżniła przebaczenie bezstronne (oderwane), ograniczone i pełne.

36 Kohlberg, „Moral stage”, 31-53.

37 Enright, Gassin, Wu. „Forgiveness”, 99-114; Enright, The Human Development Study Group, „The moral”, 123-152.

${ }^{38}$ Lawrence Kohlberg, „The cognitive-developmental approach to moral education”, Phi Delta Kappan. A Special Issue on Moral Education 56, 10 (1975): 670-677.

${ }^{39}$ McCullough, Worthington, „Models”, 2-14; Michele K. Nelson, „A new theory of forgiveness" (niepublikowana rozprawa doktorska, Purdue University, 1992); Mary F. Trainer, „Forgiveness: Intrinsic, role-expected, expedient, in the context of divorce” (niepublikowana rozprawa doktorska, Boston University, 1981); Glenn Veenstra, „Psychological Concepts of Forgiveness", Journal of Psychology and Christianity 11 (1992): 160-169. 
Veenstra opracował typologię sposobów przebaczania krzywd w relacjach interpersonalnych, zawierającą sześć następujących kategorii: (1) pomijanie krzywdy; (2) usprawiedliwianie krzywdziciela; (3) zlekceważenie wykroczenia; (4) darowanie krzywdy; (5) uwolnienie krzywdziciela od winy i (6) przywrócenie zaufania do krzywdziciela. Typologie autorstwa Trainer i Nelson zyskały potwierdzenie empiryczne. Badania wykazały również, że przebaczenie polegające na zinternalizowanych poznawczych i afektywnych zmianach odniesień wobec krzywdziciela jest związane z redukcją gniewu i negatywnego afektu oraz większą poprawą relacji ${ }^{40}$.

Typologie mogą być szczególnie użyteczne dla ukazania, że przebaczenie pojawia się z różnych motywów i rodzi różne konsekwencje. Mogą być również wykorzystywane przez doradców, o ile powstałyby techniki stymulujące zmiany poznawcze i emocjonalne charakterystyczne dla pełnego, wewnętrznego przebaczenia. Nie ma jednak pewności, czy koncepcje typologiczne mają wystarczającą wartość teoretyczną do uruchomienia lub wsparcia programów badawczych ${ }^{41}$.

\section{Pomiar przebaczenia}

Psychologowie wypracowali szereg metod do pomiaru przebaczenia rozumianego jako reakcja na krzywdę lub jako dyspozycja (tendencja) do przebaczenia.

Większość metod mierzących przebaczenie jako reakcję na konkretne doświadczenie krzywdy ma charakter samoopisowy. Pozwalają one na oszacowanie stopnia, w jakim osoba przebaczyła (lub dąży do przebaczenia) sprawcy konkretnej krzywdy. Początkowo metody te miały formę krótkich, niekiedy zawierających tylko jedno stwierdzenie skal. Dopiero w latach 80 . zaczęto konstruować skale wielowymiarowe. Jednym z pierwszych wielowymiarowych kwestionariuszy jest metoda Trainera, służąca do pomiaru czterech wskaźników przebaczenia (brak wrogości; niepodtrzymywanie urazy; pozytywny afekt wobec krzywdziciela; żywienie nadziei, że sprawcy będzie się dobrze wiodło). Trainer skonstruował także skalę mierzącą typy motywacji do przebaczenia: wewnętrzną, instrumentalną i związaną z rolą ${ }^{42}$. Innym przykładem wielowymiarowej skali samoopisowej jest kwestiona-

\footnotetext{
${ }^{40}$ McCullough, Worthington, „Models”, 2-14.

41 Tamże.

${ }^{42}$ McCullough, Hoyt, Rachal, ,What we know”, 67-68.
} 
riusz Enrighta (Enright Forgiveness Inventory - EFI). Metoda ta zawiera sześć podskal mierzących zakres, w jakim osoba doświadcza pozytywnych i negatywnych myśli, uczuć i zachowań (lub intencji zachowań) wobec sprawcy krzywdy ${ }^{43}$. McCullough skonstruował z kolei kwestionariusz (The Transgression-Related Interpersonal Motivations Inventory - TRIM) mierzący dwa negatywne aspekty motywacyjne przebaczenia: unikanie sprawcy krzywdy i poszukiwanie zemsty ${ }^{44}$.

Druga kategoria metod zawiera skale służące do pomiaru przebaczenia rozumianego jako dyspozycja lub tendencja do przebaczenia innym (lub dążenia do uzyskania przebaczenia w sytuacji, gdy osoba sama zawiniła wobec innych). Metody te pozwalają na oszacowanie pewnego zgeneralizowanego stylu reagowania na krzywdę, niezależnego od rodzaju krzywdy, a nawet niezwiązanego z charakterem indywidualnej relacji ze sprawcą krzywdy. Większość metod w tej grupie posiada również charakter samoopisowy. Za przykład może posłużyć skala gotowości do przebaczenia (The Willingness to Forgive Scale) skonstruowana przez Hebla i Enrighta. Metoda ta zawiera 16 scenariuszy opisujących różne kategorie krzywd. Zadaniem osób badanych jest przeczytanie każdego scenariusza i wyobrażenie sobie, że zostali skrzywdzeni przez inną osobę. Na końcu badani wybierają jedną z 10 hipotetycznych odpowiedzi wskazujących na to, jak zachowaliby się w sytuacji danej krzywdy oraz jak chcieliby się zachować ${ }^{45}$.

Chociaż w zakresie pomiaru przebaczenia psychologowie poczynili znaczny postęp, większość istniejących narzędzi ma charakter samoopisowy. Wciąż stosunkowo niewiele jest narzędzi służących do oceny przebaczenia z perspektywy innych osób oraz miar opartych na wskaźnikach behawioralnych, pozwalających na przykład na ocenę gotowości do przebaczenia na podstawie obserwacji zachowania człowieka w sytuacjach realnych.

\section{Wybrane psychospołeczne korelaty przebaczenia}

Wykorzystując istniejące narzędzia, badacze rzucili nowe światło na niektóre aspekty przebaczenia. Przedmiotem szczególnego zainteresowania

${ }^{43}$ McCullough, van Oyen Witvliet, „The Psychology”, 446-458.

${ }_{44}$ Michael E. McCullough, Chris K. Rachal, Steven J. Sandage, Everett R. Worthington, Susan Wade Brown, Terry L. Hight, „Interpersonal forgiving in close relationships: II. Theoretical elaboration and measurement", Journal of Personality and Social Psychology 75,6 (1998): 1586-1603.

${ }^{45}$ McCullough, Hoyt, Rachal, „What we know”, 73-74. 
cieszyła się problematyka rozwoju gotowości do przebaczenia w biegu życia człowieka, poszukiwanie osobowościowych i społecznych predyktorów przebaczenia oraz jego funkcji w zakresie zdrowia i dobrostanu.

Istniejące dane empiryczne potwierdziły, że gotowość do przebaczenia wzrasta z wiekiem. W przypadku wszystkich scenariuszy opisujących krzywdę wykorzystywanych w badaniach prawdopodobieństwo przebaczenia u osób dorosłych było istotnie wyższe niż u adolescentów. Enright dodatkowo wykazał, że etap rozumienia pojęcia przebaczenia był związany z etapem rozwoju moralnego, ocenianym za pomocą wywiadu opracowanego przez Kohlberga ${ }^{46}$.

Szereg uzyskanych danych empirycznych wskazuje, że osoby skłonne do przebaczenia cechuje: słabszy afekt negatywny (niższy niepokój, depresyjność i wrogość), niższa tendencja do przeżywania i zatapiania się we własnych myślach, niższe nasilenie cech narcystycznych oraz mniejsza skłonność do wykorzystywania innych - w porównaniu do osób o niskiej gotowości do przebaczenia. Spośród pięciu cech osobowości (ekstrawersja, neurotyczność, otwartość na doświadczenie, ugodowość i sumienność) przebaczenie korelowało dodatnio z ugodowością i ujemnie z neurotycznością. Badania potwierdziły również warunkowanie gotowości do przebaczenia przez niektóre czynniki sytuacyjne. Ludzie doświadczają większych trudności w przebaczeniu tych krzywd, które postrzegają jako poważne, wyrządzone im w sposób zamierzony i mające negatywne konsekwencje. Również stopień, w jakim sprawca krzywdy wyraża skruchę i prosi o wybaczenie, zwiększa prawdopodobieństwo udzielenia przebaczenia. Efekt prośby o przebaczenie ma charakter pośredni i zachodzi poprzez redukcję negatywnych uczuć i wzrost empatii u ofiary krzywdy wobec sprawcy. Prawdopodobnie skrucha i słowa przeproszenia ułatwiają odróżnienie osoby sprawcy od jej negatywnego czynu. Gotowość do przebaczenia zależy również od charakteru relacji interpersonalnej, w której krzywda została wyrządzona. Badania potwierdzają że ludzie chętniej przebaczają, jeśli relacja ze sprawcą krzywdy była dla nich satysfakcjonująca, bliska i byli w nią zaangażowani ${ }^{47}$.

Większość badań nad funkcją przebaczenia koncentrowała się na wykazaniu jego powiązań ze zdrowiem. Samoopisowe miary gotowości do przebaczenia korelowały dodatnio ze wskaźnikami zdrowia psychicznego i dobrostanu. Gotowość do przebaczenia innym wiązała się ujemnie z depresją, gniewem, niepokojem i dodatnio z poczuciem wartości. Podobnie

\footnotetext{
46 McCullough, van Oyen Witvliet, „The Psychology”, 449.

47 Tamże, 450.
} 
tendencja do przebaczenia sobie korelowała ujemnie z depresją, wyobrażeniami paranoidalnymi, nadwrażliwością interpersonalną i psychotyzmem. Takiej jednoznaczności nie odnotowano jednak w badaniach nad związkiem zdrowia z przebaczeniem definiowanym jako reakcja na konkretną krzywdę. Badania poprzeczne ujawniły słabe (dodatnie) lub nieistotne zależności satysfakcji z życia od przebaczenia, ale badania longitudinalne prowadzone na przestrzeni ośmiu tygodni nie potwierdziły tych zależności. Pewnym metodologicznym problemem, jaki nieuchronnie pojawia się $\mathrm{w}$ badaniach nad związkiem przebaczenia $\mathrm{z}$ dobrostanem i zdrowiem psychicznym, jest fakt, że istniejące narzędzia operacjonalizują przebaczenie za pomocą negatywnego lub pozytywnego afektu odczuwanego przez ofiarę wobec sprawcy krzywdy, a zdrowie psychiczne - za pomocą samoopisowych miar afektu (np. depresyjność lub niepokój). Obserwowane zależności mogą więc być rezultatem raczej pokrewieństwa semantycznego niż rzeczywistego powiązania tych zmiennych.

\section{Psychological Concepts of Forgiveness in Interpersonal Relations (Summary)}

In philosophy and theology, in particular Christian theology, the notion of forgiveness has been discussed since a long time ago. In psychology, the increase in interest in forgiveness is dated back to the end of the 80's of the 20th century. It had its origins in the clinical practice. On one hand, practitioners of psychology noticed that it is possible to apply forgiveness in the therapy of those who were wronged, in particular those who fell victim to sexual abuse, incest and domestic violence. Researchers of psychology, on the other hand, took steps to define and measure forgiveness, and to explore its predictors and functions in the area of well-being and the quality of life.

The aim of the present research is showing forgiveness from the psychological perspective. The first part includes the overview of definitions of forgiveness elaborated within psychotherapy, pastoral psychology, social psychology and developmental psychology. Next, the authors presented psychological models of forgiveness and methods of its measurement. The last part includes the preview of certain results of research on psychological-social correlates of forgiveness and on its relationship with the indicators of mental health and well-being.

Key words: forgiveness in psychology; models of forgiveness; measurement of forgiveness; correlates of forgiveness. 


\section{Psychologiczne koncepcje przebaczenia w relacjach międzyludzkich (Streszczenie)}

Przebaczenie ma długą historię rozważań na polu filozofii i teologii, zwłaszcza teologii chrześcijańskiej. W psychologii wzrost zainteresowania problematyką przebaczenia datuje się na koniec lat 80 . XX wieku. Miało ono swoje źródło przede wszystkim w praktyce klinicznej. Psychologowie praktycy dostrzegli możliwość zastosowania przebaczenia w terapii osób skrzywdzonych, zwłaszcza ofiar nadużyć seksualnych, kazirodztwa i przemocy domowej. Badacze poczynili z kolei postępy w definiowaniu i pomiarze przebaczenia, a także w eksploracji jego predyktorów i funkcji w obszarze dobrostanu oraz jakości życia.

Celem prezentowanego artykułu jest ukazanie zjawiska przebaczenia w perspektywie psychologicznej. Część pierwsza zawiera przegląd definicji przebaczenia wypracowanych na obszarze psychoterapii, psychologii pastoralnej, psychologii społecznej i rozwojowej. Następnie przedstawiono psychologiczne modele przebaczenia oraz metody jego pomiaru. Ostatnia część zawiera omówienie niektórych rezultatów badań nad psychospołecznymi korelatami przebaczenia oraz jego związkiem ze wskaźnikami zdrowia psychicznego i dobrostanu.

Slowa kluczowe: przebaczenie w psychologii; modele przebaczenia; pomiar przebaczenia; korelaty przebaczenia.

\section{Bibliografia}

Augsburger, David W. Sztuka przebaczania. Warszawa: Vocatio, 1995.

Bartczuk, Rafał P. „Postawa religijna a gotowość do przebaczenia. Badania empiryczne". Niepublikowana praca magisterska, Katolicki Uniwersytet Lubelski, 1999.

Benson, Colleen K. „Forgiveness and the psychotherapeutic process”. Journal of Psychology and Christianity 11 (1992): 76-81.

Droll, David M. „Forgiveness, Theory and research”. Niepublikowana rozprawa doktorska, Uniwersytet Nevady, 1984.

Enright, Robert D. The Human Development Study Group, „Counseling with the forgiveness triad: On forgiving, receiving forgiveness, and self-forgiveness”. Counseling \& Values 40, 2 (1996): 107-126.

Enright, Robert D. „Piaget on the moral development of forgiveness: Identity or reciprocity?". Human Development 37, 2 (1994): 63-80. 
Enright, Robert D. „The moral development of forgiveness”. Handbook of moral behavior and development 1 (1991): 123-152.

Enright, Robert D, The Human Development Study Group, ,The moral development of forgiveness". W: Moral behavior and development, t. 1, red. William M. Kurtines, Jacob Gewirtz, 123-152. Hillsdale, NJ: Erlbaum, 1991.

Enright, Robert D., Catherine T. Coyle. ,Researching the process model of forgiveness within psychological interventions". W: Dimensions of forgiveness: Psychological research and theological perspectives, red. Everett L. Worthington jr, 139-161. Philadelphia-London: Templeton Foundation Press, 1998.

Enright, Robert D., Elizabeth A. Gassin, Ching-Ru Wu. „Forgiveness: A developmental view". Journal of Moral Education 21 (1992): 99-114.

Enright, Robert D., Maria JD Santos, Radhi Al-Mabuk. „The adolescent as forgiver". Journal of adolescence 12, 1 (1989): 95-110.

Fitzgibbons, Richard P. „The cognitive and emotive uses of forgiveness in the treatment of anger". Psychotherapy: Theory, Research, Practice, Training 23, 4 (1986): 629-633.

Freedman, Suzanne R., Robert D. Enright. „Forgiveness as an intervention goal with incest survivors". Journal of Consulting and Clinical Psychology 64, 5 (1996): 983-992.

Freedman, Suzanne, Tiffany Zarifkar. „The Psychology of Interpersonal Forgiveness and Guidelines for Forgiveness Therapy: What Therapists Need to Know to Help Their Clients Forgive". Spirituality in Clinical Practice, DOI: http:// dx.doi.org/10.1037/scp0000087.

Gartner, John. ,The capacity to forgive: An object relations perspective”. Journal of Religion and Health 27, 4 (1988): 313-320.

Gruszecka, Eufrozyna. „Trudności w wybaczaniu krzywd osobistych”. Nowiny Psychologiczne 1 (1996): 41-55.

Jacyniak, Aleksander, Zenomena Płużek. Świat ludzkich kryzysów. Kraków: WAM, 2006.

Kaminer, Debra, Dan J. Stein, Irene Mbanga, Nompumelelo Zungu-Dirwayi. „Forgiveness: Toward an integration of theoretical models". Psychiatry 63,4 (2000): 344-357.

Kelly, George A. The psychology of personal constructs. New York: Norton, 1955.

Kohlberg, Lawrence. „Moral stage and moralization: The cognitive-developmental approach to socialization". W: Moral development and behavior: Theory, research, and social issues, red. Thomas Lickona, 31-53. New York: Holt, Rinehart and Winston, 1976.

Kohlberg, Lawrence. ,The cognitive-developmental approach to moral education”. Phi Delta Kappan. A Special Issue on Moral Education 56, 10 (1975): 670-677. 
Lapsley, James N. „Reconciliation, forgiveness, lost contracts”. Theology Today 23, 1 (1966): 44-59.

Lin, Wei Neng, Robert D. Enright, John S. Klatt. „A forgiveness intervention for Taiwanese young adults with insecure attachment". Contemporary Family Therapy 35,1 (2013): 105-120.

Linn, Dennis, Matthew Linn. Uzdrawianie ludzkich zranień poprzez pięć etapów przebaczenia. Kraków: Wydawnictwo M, 1993.

Martin, Arthur J. „A realistic theory of forgiveness”. W: The return to reason, red. John Wild, 313-332. Chicago: Henry Regnery, 1953.

McCullough, Michael E. „Forgiveness as human strength: Theory, measurement, and links to well-being". Journal of Social and Clinical Psychology 19, 1 (2000): 43-55.

McCullough, Michael E., Charlotte van Oyen Witvliet. „The Psychology of Forgiveness". W: Handbook of positive psychology, red. Charles R. Snyder, Shane J. Lopez, 446-458. New York, NY: Oxford University Press, 2002.

McCullough, Michael E., Chris K. Rachal, Steven J. Sandage, Everett R. Worthington, Susan Wade Brown, Terry L. Hight. „Interpersonal forgiving in close relationships: II. Theoretical elaboration and measurement". Journal of Personality and Social Psychology 75, 6 (1998): 1586-1603.

McCullough, Michael E., Everett L. Worthington. „Models of interpersonal forgiveness and their applications to counseling: Review and critique". Counseling and Values 39, 1 (1994): 2-14.

McCullough, Michael E., William T. Hoyt, Chris Rachal. „What we know (and need to know) about assessing forgiveness constructs". W: Forgiveness: Theory, research, and practice, red. Michael E. McCullough, Kenneth I. Pargament, Carl E. Thoresen, 65-88. New York-London: The Guilford Press, 2000.

Mellibruda, Jerzy. Pułapka niewybaczonej krzywdy (Instytut Psychologii Zdrowia i Trzeźwości. Polskie Towarzystwo Psychologiczne, 1995).

Nelson, Michele K. „A new theory of forgiveness”. Niepublikowana rozprawa doktorska, Purdue University, 1992.

Ostrowska, Krystyna. Wokót rozwoju osobowości i systemu wartości. Warszawa: Centrum Metodyczne Pomocy Psychologiczno-Pedagogicznej MEN, 1998.

Pettitt, Guy A. „Forgiveness: A teachable skill for creating and maintaining mental health". New Zealand Medical Journal 100 (1987): 180-182.

Pingleton, Jared P. „The role and function of forgiveness in the psychotherapeutic process". Journal of Psychology and Theology 17 (1989): 27-35.

Rokeach, Milton. The nature of human values. New York: Free Press, 1973.

Smith, Michael. „The psychology of forgiveness”. The Month 14 (1981): 301-307 . 
Trainer, Mary F. „Forgiveness: Intrinsic, role-expected, expedient, in the context of divorce". Niepublikowana rozprawa doktorska, Boston University, 1981.

Veenstra, Glenn. „Psychological Concepts of Forgiveness”. Journal of Psychology and Christianity 11 (1992): 160-169.

Woydyło, Ewa. Aby wybaczyć. Warszawa: Akuracik, 1998. 